DOI: https://doi.org/10.32839/2304-5809/2019-2-66-102

UDC 37.013

Kovalenko Oksana

Simon Kuznets Kharkiv National University of Economics

\title{
COMMUNICATION IN THE PROCESS OF EDUCATION
}

Summary. Communication in the educational process ia regarded as a description of person and a total peculiarities, capacities and the quality of the student conditioned by the cooperation of characters of the communication. The process of somebody`s personal development is creatied within limits of the communication. One of the biggest challenges of everything involving teaching is, beyond doubt, reaching out to students and getting them involved in the learning process. In the following we will analyze the relationship between teacher and student, the mechanism of educational communication, implications of affectivity in the trainertrainee relation, the phases of didactic communication and its psycho-pedagogical implications, as well as the managerial communication. Although the modern man feels the absence of real communication because it seems to address everyone, in modern times we find the culmination of communication.

Keywords: teaching, education6 communication, learning processes, teacher student relationship.

Коваленко О.Ю.

Харківский національний економічний університет імені Семена Кузнеца

\section{КОМУНІКАЦІЇ В ОСВІТНЬОМУ ПРОЦЕСІ}

Анотація. Комунікаціями пронизані всі сфери людського життя, у тому числі й освітня діяльність. У статті розкрито особливості смислового наповнення поняття «комунікація» відповідно до наявних соціального, гуманістичного підходів. Описано основні характеристики комунікативних процесів на ринку освітніх послуг. Комунікації в освітньому процесі розглядаеться як характеристика особи, сукупність особливостей, здібностей і якостей особи, обумовлених взаємодією суб'єктів інтерактивної комунікації, у рамках якої моделюеться процес його особового розвитку. Розвиток комунікативних здібностей проявляється на основі стійко використовуваних способів рішення завдань і внутрішніх процесів самозвеличання. Оптимальним варіантом професійної комунікації є зв'язок студент-викладач. Це залежить не лише від наукових можливостей лідера наукової школи, а і його здатності безпосередньо спілкуватися зі своїми студентами. Чим тіснішими е комунікаційні зв'язки між усіма фігурантами наукового і навчально-виховного процесу, тим збільшуеться рівень його результативності. Звісно, комунікаційний зв'язок студент-викладач не обмежується лише науковою і навчально-виховною діяльністю, він зумовлений характером особистості як викладача, соціальною самопрезентацією. В арсеналі сучасного викладача існують багатоканальні способи комунікаційного зв’язку зі студентами. У разі необхідності він може успішно скористатися для спілкування зі своїми студентами всією системою комунікаційних каналів, засобів і способів або надати перевагу одному з них. рівня розвитку закладів освіти. Розвиток комунікацій створює умови для передачі інформації до споживачів освітніх послуг, що є дуже важливим для сучасного освітньго процесу. Процес комунікацій достатньо складний й багатогранний.

Ключові слова: навчання, освіта, комунікація, навчальні процеси, взаємодія студент-викладач.

Tntroduction. Communwcation is the process

1 of transmission from one individual to another and from one group to another social group, meaning, in fact, life and the possibility of people's coexistence.

Novelity. In the modern pedagogy, the relationship between the teacher and the student is conceived as a complex complex relation, involving the permanent dialogue between the factors involved in the educational process, a mutual communication that engages the personalities of their personality. The teacher activates and maintains the investigative activism of the student, creates favorable conditions for the student to discover, to put problems and tasks of knowledge. The age in which the teacher merely proposed the content, gave lessons and formed tasks had long gone.

Presentation of the main research material. University is an institution that plays a significant role in a student's life. Being an active employee in this institution, a teacher should be democratic, tender, patient, reliable and humorous to his/ her students during the interaction and communication processes so that the teaching and learning processes are affected positively. It is important to create a common living space in the classroom for students that have different family, economic, cultural and living backgrounds in order to achieve better motivation and learning. In the common living space in the classroom, the teacher creates a common living space with the students while the students do the same thing among themselves and accordingly a common synergy is created.

The most important component of education is a student. Teachers' interactions, ways of communication and verbal-nonverbal behaviors, class management and activities affect not only students' behaviors but also teaching system directly [6]. It is inevitable for teachers who are responsible for the education industry to have a policy and behavior. A teacher who always interacts with students is responsible for planning activities of teaching and application. Being a qualified teacher plays an important role in providing sit's quality disposed behavior [6].

Interaction simplifies the process of communication between teachers and students and provides them with the formation of a shared common area. During the enlargement of distracters can be easily 
destroyed though communication. Communication is the key of education, teaching and learning and it affects the life of an individual throughout his/ her whole life.

As communication is an important concept related to all sciences (communication is a multi-disciplined concept) it has lots of definitions. Education and learning is a part of life. In this process, communication helps determining negative changes in behaviors and expressing ideas and thoughts in mind as well as affecting others. Today, the importance of communication increasingly rises because it is the fundamental tool of information transfer. That is why this era is called Information era. Individuals can form shared common areas through knowledge, technology and interaction. When the concepts of education, teaching and teacher are of concern, forming shared common areas is compulsory.

This study is a descriptive study which includes interaction, communication and shored common life areas. It is a theoretical study concerning shared common life areas inside the classroom.

Interaction and Communication. Everyone must communicate. But teachers need communication more than anyone. It is an obligation. The only to communication is through interaction. Teachers should affect students are in order to interact; they should be democratic, tolerant, smiling, lovable, patient and reliable. If they want to teach in an effective way in the process of learning and teaching, they should interact properly. However, teachers can make use of communication as long as they learn communication factors.

The reliability of the source is the most important factor in the process of communication. When people receive messages from the source and then send the feedback, they in fact, complete the process of interaction even without other supportive messages. If the sources, is reliable, communication grocers will, of course be completes more easily $[7 ; 10]$. So, teachers should be balanced for a better interaction and communication. If not, there is no reed to talk about trustworthiness. Besides it will bring about new problems.

Moreover the source should present objective approaches. Any kind of behavior which damages objectivity should be prevented to stop communication conflicts.

Teachers who want to communicate effectively should predict the behaviors of students. As they are the ones who contact, and always speak in front of big groups, they are the pioneers of social behaviors. So they should cope with feelings and conflicts. When they cope with such difficulties, they use non-verbal tools to support verbal expressions most of the time. For example, if teachers speak in a proper voice during the presentation of knowledge students, of course, will be more motivated in the classroom. So teachers should use their voices up and down and, thereby, take attention to important points. During classes, it plays an important role in combination with walking and takes the attention of students in the classroom.

In order to make positive connections, teachers should control their behaviors and understand the body language of their student. Body posture, gesture and mimics, in short non-verbal communication is important in the process of teaching and learning [10].
Teachers should also see the stase from the distance in the right position and stare at a student or a group of student in a dense manner and should contract with the whole class. Long rooks should be evaluated for the teaching job, which means being dominant and threatening. It makes a person aggressive and enables teachers to tesk what students are more dominant.

Distance is also an important component in personal relationships. From a distance students should feel motivated in order to study, but they should not feel themselves trapped in the classroom.

In order to be understood by others, body language and signals should be known [6]. The way to communicate effectively in the process of education depends on the element which is going to provide communication. So, in order to interact and communicate in the classroom, the criteria below should be considered:

The teacher must use an explicit language and should abstain from language.

Teachers should analyze students' thoughts from their body reactions, control their own body reactions and use body language consciously.

Teachers should annihilate the distracters which decrease the concern of student.

Teachers should have enough knowledge of method and techniques. They should teach all subjects and units.

Teachers should know the properties of tools and materials well and use them in a professional manner.

Teachers should conduct classes like a game in order to facilitate and motivate learning. Because children learn about life through games.

Teachers should choose tools and equipment that motivate students most.

Teachers should use the feedback mechanism in effective ways and should evaluate feedbacks instantly.

Other stimulants (lovely odours, wearing different clothes, etc.) should be applied.

Teachers should always come and leave the class on time.

During learning activities, if the shared common life area is wide, there will be an increase in success. The teacher in the classrooms is responsible for conducting the message. So, he/she should know the attributes of receivers and make the environment rich by using several channels [10].

One of the most components elements of communication is that communication is based on cultural sources. So family environment where individuals are brought up should also be considered in the process of communication.

Teachers should have sufficient knowledge about valves which will enable them to communicate with students. They should be well equipped about what ways to use to communicate with students and about the valves they acquire in the daily life; as a result they will use it to increase their communication skills [7].

As each individual has a different family back ground, he/she will differ in his/her belief system and economical and social statuses. Thus, it is nor$\mathrm{mal}$ for him/her to perceive his/her cultural environment differently compared to others. What teachers have to do is that they should consider those 
differences during the communication process. One of the most important components teacher should figure out is to from shared common areas between themselves and students, because, students from different family backgrounds relate with their peers and teachers in the process of interaction and communication. So, if a shared common life area is large between two individuals, there will be more communication opportunities between them [2]. In short, for an effective communication among individuals, teacher should consider the culture concept in the process of communication [4]. Besides, it should be noted that students from different social economical and cultural backgrounds also from shared common life areas among in the process of interaction and communication in the classroom. The figure below shows this situation.

Cultural harmony plays an important role in forming positive relationships between teachers and students. If individuals have backgrounds, they can communicate more easily [8]. If teachers and students have less shared common areas, it can be difficult to communicate effectively and some conflicts may occur.

Teachers should consider the cultural attributes of students in the communication otherwise; the authority of teachers can be weakened as a result of the resistance of some children. So, teachers should be balanced in their approaches and behave according to students' cultural environments [9].

Teachers who know how to interact and communicate are able to analyze students, bring a shared common area out of different cultures and make the teaching learning process more active and enjoyable.

Conclusion. In order to provide interaction with his/her students, a teacher should be democratic, lovable, patient, and reliable and have a sense of humors. If he/she not have those attributes, he/she cannot interact with his/her students. So, oral and writing examination should be applied in order to evaluate teachers' interaction and communication performances before recruiting them.

All people should communicate but teachers are of concern, communication when becomes more and more important. Because an effective learning-teaching process cannot work without communicating. In order to communicate effectively, teachers should be balanced, reliable and have the ability to use different channels. As a result, in order to provide teachers with better interaction and communication, we should support the area of interaction and communication.

Teachers, who affect the learning-teaching process, should from shared common life areas with the students who come from different social, economical and cultural backgrounds. The more a teacher forms a shored common life area, the more he/ she forms an effective learning-teaching process. So, he/she should try to know what students come from different backgrounds. Furthermore, pedagogy courses for teachers to be should give added valve to cultural differences in their curriculum

Teachers, finally, should not only interact with students who come from different backgrounds but also let them from a shared common area in the classroom. This will also support universal culture.

Nothing exists outside communication. As in any field, it is extremely important in education to master all means of communication, both to succeed in creating students with a harmoniously developed personality with sound knowledge in different fields and with welldefined skills and abilities to help them to become as complex as possible.

In modern pedagogy, communication has an increasingly important place, perhaps the most important. Managers, teachers, students who understand this have found the recipe that can guarantee success at the end of the study period.

\section{References:}

1. Baker C. (2011). Foundations of Bilingual Education and Bilingualism, Clevedon : Multilingual Matters, (4th edition).

2. Merzliakova O. (2008). Uchyteli y uchni; mystetstvo dialohu: seminar ta treninhovi zaniattia psykholoha z pedahohamy [Teachers and students; art of dialogue: workshop and psychological training sessions with teachers]. Shk. svit, Kyiv, p. 352.

3. Mesch G.S. (2009). The Internet and Youth Culture, The Hedgehog Review (online). Available at: http://www.iasc-culture.org/THR/archives/YouthCulture/Mesch.pdf. Spring (accessed 1 February 2019).

4. McCrindle M. (2015). Education \& learning styles, Generation Z. (online). Available at: http://generationz.com.au/ (accessed 1 February 2019).

5. Savenkova L.O. (1998). Komunikatyvnist uchytelia. Pochatkova shkola, vol. 8, pp. 49-51.

6. Savenkova L.O. (1998). Komunikatyvna ataka» u formuvanni navychok pedahohichnoho spilkuvannia. Pedahohika i psykholohiia, vol. 4, pp. 100-106.

7. Singla R.K. (2011). Communication: Nature, Process and Network. Business organisation and management. Delhi : J.N. Printers.

8. Universal Declaration on Cultural Diversity Accessed 9 January 2011, 2011 (online). Available at: http: //unesdoc.unesco.org/images/0012/001271/ 127160m.pdf (accessed 20 February 2019).

9. Zabrotskyi M.M. (2009). Komunikatyvna kompetentnist vchytelia: ekopsykholohichnyi vymir. Praktychna psykholohiia ta sotsialna robota, vol. 6, pp. 1-4. 